\title{
A Study of Body Mass Index in Relation to Motor Fitness Components of School Going Children Involved in Physical Activities
}

\author{
Sharma ${ }^{1}$, R. and Nigam ${ }^{2}$, A. K. \\ ${ }^{1}$ Grade-I Gymnastic-Coach, S.A.I Traning Centre, Department of Sports and Youth Welfare, District Sports \\ Complex, Bilapur (C.G.), India. \\ ${ }^{2}$ Assistant Professor Department of Physical Education, Guru Ghasidas Central University Bilaspur (CG), India.
}

\section{Abstract}

The purpose of the study was to evaluate and compare the motor fitness in relation to Body Mass Index of school going children involved in physical activities. One hundred school going male children of $9^{\text {th }}$ and $10^{\text {th }}$ grade were selected to serve as subjects for this study. The researcher divided the entire 100 sample into three groups. i.e. Low BMI $(\mathrm{N}=25)$, middle BMI $(\mathrm{N}=50)$ and High BMI (N=25) groups, which were compared with each other. All the subjects were tested on Chin ups, Vertical Jump, Shuttle Run, Sit and Reach and BMI (Body Mass Index). In order to find out the significance of differences between the three BMI groups male children, mean, standard deviation, quartile deviation (Q1 and Q3) and t-ratio were computed. The results of the study revealed non significant differences between Low BMI and High BMI groups in their vertical jump, flexibility, chin-ups components of motor fitness. Low BMI group children were however found to be better in muscular strength, speed, and agility and similar on flexibility compared to high BMI group children. Low BMI group was also better on speed and agility components of motor fitness than the middle BMI group children and was similar in other components of fitness. Whereas, middle BMI group children were superior on muscular strength, speed, and agility and similar on vertical jump and flexibility components of fitness in comparison to high BMI group children.

\section{Key words: Body Mass Index, Motor Fitness Components}

\section{Introduction}

The term motor fitness is most often used synonymously with physical fitness by the coaches but it is very important for the physical education students to understand the basic difference between physical fitness and motor fitness. Physical fitness is used to denote only the five basic fitness components (muscular strength, muscular endurance, cardiovascular endurance, freedom from obesity and flexibility), whereas motor fitness is a more comprehensive term, which includes all the ten fitness components including additional five motor performance components (power, speed, agility, balance and reaction time), important mainly for success in sports. In other word, motor fitness refers to the efficiency of basic movements in additional to the physical fitness (Kansal, 1996).

Physical educators, exercise physiologists, and physicians have proposed many tests to demonstrate the effect of such programs. These tests have generally been labeled "Motor Fitness Test" "Physical Fitness Tests" and 
"Cardiovascular Tests". Additional tests have been developed by many colleges and universities. With so many groups and individuals promoting different fitness test, the practitioner my easily become confused especially when the same items appears in both motor and physical fitness tests. Thus one might ask whether there is a difference between motor fitness and physical fitness. Are the dimensions of fitness equally relevant to all the people of all ages? Obviously, the nature of fitness- what it means to the participant the type of fitness activities selected, the intensity and duration of exercise- vanes with aging among school children through adulthood, the middle age, and old age. In other words, finesses is specific to the needs of different populations. This is reflected in the perennial question. "Fitness for what?"

The importance of an optimal level of physical fitness as a reflection of certain aspects of health was demonstrated by the work of Kraus and Raab (1961) on hypo-kinetic diseases, or diseases directly related to a lack of exercise. These physicians identified low back pain, foot problems, abdominal posies, obesity, hypertension, and degenerative cardiovascular diseases as conditions produced by sedentary lifestyles in our affluent, tension-producing society. Thus the concept of physical fitness does convey a meaning of healthful living. Because heart disease, stroke and circulatory disorders are still primary causes of poor fitness is highly relevant for all people. Sedentary people suffer a higher incidence of coronary heart diseases than active persons (Morris et. al. 1973., Paffenbarger \& Hale 1991). Thus attaining a desirable level of physical fitness is an important aspect of preventive medicine because physical 30 inactivity appears to be related to the coronary heart disease. Recent longitudinal data shows that Harvard alumni who expend 2000 calories a week in vigorous exercise during their life span will increase the quality of life as well as live one or more years longer than sedentary persons. For most young participants however a physical fitness test is one that attempts to measure the efficiency of both the muscular and cardiovascular systems.

Body Mass Index (BMI) is a ratio of total body weight to height. Several ratios have been proposed, but one used most frequently. Weight (in kilograms) divided by height (in meters) square [weight, $\mathrm{kg} / \mathrm{ht}, \mathrm{m}^{2}\left(\mathrm{~kg} / \mathrm{m}^{2}\right)$ ]. Calculated BMI can then be compared against standard value to determine whether the individual has acceptable body weight, is overweight, or is obese. Risk of increased mortality from high values of body mass index (BMI) is described by a $\mathbf{J}$ - shaped curve. BMI value from 15 to 25 represents no excess mortality risk and over 40 a high risk of great mortality. (Brary, 1985).

The purpose of the present study was to evaluate and compare the motor fitness and Body Mass Index of school going children of D.P.S. Public school"

\section{Materials \& Methods}

One hundred school going male children of $9^{\text {th }}$ and $10^{\text {th }}$ grade who volunteered to participate in this study, were selected to serve as subjects for this study. The subjects were in age group of 13 to 16 years. All the subjects' were selected from the 9th and 10th grades of Delhi Public School, Bilaspur (CG). The subjects were explained about the purpose of study in the 
presence of their school physical education teachers and Principal to elicit active cooperation from the subject. All the subjects were tested on Chin ups, Vertical Jump, Shuttle Run, Sit and Reach and BMI (Body Mass Index) and scoring of data for each test was done following standard techniques as described by Kansal (1996).

All the tests were administered at Delhi public school, Bilaspur (CG) playground.

\section{Results \& Discussion}

To verify the hypotheses, Q1 and Q3 of BMI were calculated. Q1 score of BMI is 19.57, it means subject were having > 19.57 or 19.57 and $<24.56$ or 24.56 for high BMI group and the subject whose BMI calculated between Q1 and Q3 were in middle BMI group.

The researcher divided the entire 100 sample into three groups on basis of calculated quartile deviations (Q1 and Q3). Subjects having BMI values between $\mathrm{Q}_{1}$ and $\mathrm{Q}_{3}$ were put in the middle BMI group $(\mathrm{N}=50)$. Subjects possessing $\mathrm{BMI}$ values $>\mathrm{Q}_{3}$ were put in High BMI group $(\mathrm{N}=25)$ while those having $\mathrm{BMI}$ values $<\mathrm{Q}_{1}$ were assigned to the low BMI group $(\mathrm{N}=25)$.

In order to find out the significance of differences between middle BMI and high BMI of school going children means, standard deviations, quartile deviation (Q1 and Q3) and t-ratios were computed. To check the obtained F-ratio and t-ratio, the level of significance was set at 0.05 level and data pertaining to this have been presented in Tables 1 to 4 .
Table No. 1: Descriptive Statistics of Body Mass Index (BMI) on various components of motor fitness of school going male children of IX and X Grade

\begin{tabular}{|c|c|c|c|c|c|c|}
\hline & \multicolumn{2}{|c|}{$\begin{array}{c}\text { LOW BMI } \\
(\mathrm{N}=25)\end{array}$} & \multicolumn{2}{|c|}{$\begin{array}{l}\text { AVERAGE } \\
\text { BMI (N=50) }\end{array}$} & \multicolumn{2}{|c|}{$\begin{array}{c}\text { HIGH BMI } \\
(\mathrm{N}=25)\end{array}$} \\
\hline & Mean & SD & Mean & SD & Mean & SD \\
\hline $\begin{array}{l}\text { Vertical } \\
\text { Jump }\end{array}$ & 35.10 & 7.51 & 35.76 & 7.49 & 35.54 & 8.21 \\
\hline $\begin{array}{l}\text { Chin } \\
\text { ups }\end{array}$ & 7.88 & 1.70 & 7.1 & 2.66 & 5.00 & 1.66 \\
\hline $\begin{array}{l}\text { Shuttle } \\
\text { run }\end{array}$ & 12.44 & 0.89 & 12.90 & 0.70 & 13.72 & 0.89 \\
\hline $\begin{array}{l}\text { Sit and } \\
\text { Reach }\end{array}$ & 2.96 & 1.81 & 3.00 & 1.87 & 2.76 & 1.71 \\
\hline
\end{tabular}

Table No. 2: Significance of differences between mean scores of middle and high BMI of school going male children on various components of motor fitness

\begin{tabular}{|c|c|c|c|c|c|}
\hline $\begin{array}{l}\text { MOTOR } \\
\text { FITNESS }\end{array}$ & $\begin{array}{c}\text { BMI } \\
\text { GROUPS }\end{array}$ & MEAN & MD & DM & $\begin{array}{c}\text { T- } \\
\text { RATIO }\end{array}$ \\
\hline Vertical & & & \multirow{2}{*}{0.22} & \multirow{2}{*}{0.024} & \multirow{2}{*}{0.11} \\
\hline Jump & High & 35.54 & & & \\
\hline Chin ups & $\begin{array}{l}\text { Middle } \\
\text { High }\end{array}$ & $\begin{array}{l}7.10 \\
5.00\end{array}$ & 2.10 & 7.603 & $3.62 *$ \\
\hline $\begin{array}{l}\text { Sit and } \\
\text { Reach }\end{array}$ & $\begin{array}{l}\text { Middle } \\
\text { High }\end{array}$ & $\begin{array}{l}3.00 \\
2.76\end{array}$ & 0.24 & 0.125 & 0.54 \\
\hline $\begin{array}{l}\text { Shuttle } \\
\text { Run }\end{array}$ & $\begin{array}{l}\text { Middle } \\
\text { High }\end{array}$ & $\begin{array}{l}12.90 \\
13.72\end{array}$ & 0.82 & 3.952 & $4.82 *$ \\
\hline
\end{tabular}

Significant at .05 level, $t .05(73)=1.99$

Table 3: Significance of differences between mean scores of low and high BMI of school going male children on various component of motor fitness

\begin{tabular}{|c|c|c|c|c|c|}
\hline $\begin{array}{l}\text { MOTOR } \\
\text { FITNESS } \\
\end{array}$ & $\begin{array}{c}\text { BMI } \\
\text { GROUPS }\end{array}$ & MEAN & MD & DM & $\begin{array}{c}\text { T- } \\
\text { RATIO }\end{array}$ \\
\hline Vertical & Low & 35.10 & \multirow{2}{*}{0.44} & \multirow{2}{*}{0.094} & \multirow{2}{*}{0.19} \\
\hline Jump & High & 35.54 & & & \\
\hline Chin ups & $\begin{array}{l}\text { Low } \\
\text { High }\end{array}$ & $\begin{array}{l}7.88 \\
5.00\end{array}$ & 2.88 & 17.51 & $6.08 *$ \\
\hline $\begin{array}{l}\text { Sit and } \\
\text { Reach }\end{array}$ & $\begin{array}{l}\text { Low } \\
\text { High }\end{array}$ & $\begin{array}{l}2.96 \\
2.76\end{array}$ & 0.20 & 0.08 & 0.40 \\
\hline $\begin{array}{l}\text { Shuttle } \\
\text { Run }\end{array}$ & High & 12.44 & 1.28 & 7.43 & $5.81 *$ \\
\hline
\end{tabular}

Significant at .05 level, $t .05(48)=2.01$

It is evident from table 2, that there statistically significant differences were observed between middle BMI - high BMI groups on chin ups and shuttle run components of motor fitness, as the obtained t-values of 3.62 and 4.82 respectively were higher than the required t-value of $\mathrm{t} .05(73)=199$. 
Similarly, statistically significant differences were observed between low BMI - high BMI on chin ups and shuttle run components of motor fitness, as the obtained t-values of 6.08 and 5.81 respectively were higher than the required $\mathrm{t}$-value of $\mathrm{t} .05(48)=2.01$ (table $3)$.

\begin{tabular}{|c|c|c|c|c|c|}
\hline $\begin{array}{l}\text { MOTOR } \\
\text { FITNESS }\end{array}$ & $\begin{array}{c}\text { BMI } \\
\text { GROUPS }\end{array}$ & MEAN & MD & DM & $\begin{array}{c}\text { T- } \\
\text { RATIO }\end{array}$ \\
\hline \multirow{2}{*}{$\begin{array}{l}\text { Vertical } \\
\text { Jump }\end{array}$} & Low & 35.10 & \multirow{2}{*}{0.66} & \multirow{2}{*}{0.231} & \multirow{2}{*}{0.35} \\
\hline & Middle & 35.76 & & & \\
\hline Chin ups & $\begin{array}{l}\text { Low } \\
\text { Middle }\end{array}$ & $\begin{array}{l}7.88 \\
7.10\end{array}$ & 0.78 & 1.021 & 1.32 \\
\hline $\begin{array}{l}\text { Sit and } \\
\text { Reach }\end{array}$ & $\begin{array}{l}\text { Low } \\
\text { Middle }\end{array}$ & $\begin{array}{l}2.96 \\
3.00\end{array}$ & 0.04 & 0.003 & 0.08 \\
\hline $\begin{array}{l}\text { Shuttle } \\
\text { Run }\end{array}$ & $\begin{array}{l}\text { Low } \\
\text { Middle }\end{array}$ & $\begin{array}{l}12.44 \\
12.90\end{array}$ & 0.46 & 1.266 & $2.70 *$ \\
\hline
\end{tabular}

Significant at .05 level, t.05 $(73)=1.99$

Table 4, reveals statistically significant differences between Low BMI - middle BMI groups on shuttle run component of motor fitness, as the obtained t-value of 2.70 was higher than the required $t$-value of $t .05(73)=199$.

\section{Discussion}

Findings of descriptive data of school going children belonging to IXth and Xth grade (Boys) of BMI (low, middle and high) on Vertical Jump, Chin ups, Sit and Reach, Shuttle Run components of motor fitness indicated that difference exists among different BMI children of school on various components of motor fitness and performance of the subjects on various components shows more improvement with middle BMI and less with Low and high BMI.

When the male school going children were compared between Middle BMI - high BMI on together on various components of motor fitness, they had significant differences in their fitness components for the chin ups and shuttle run.

When the male school going children were compared between low BMI - high BMI on together on various components of motor fitness, they had also significant differences in their fitness components for the chin ups and shuttle run. Furthermore, male school going children were compared between low BMI -middle BMI on together on various components of motor fitness, they had also significant differences in their fitness component for the shuttle run only.

It was also hypothesized that "The students with Less Body Mass Index would show high level of motor fitness" is partially accepted, as male school going children were high on chin ups in comparison with middle and high BMI. Middle Body Mass Index students showed high level of motor fitness on vertical jump and sit and reach chin ups in comparison with low and high BMI male school going children, whereas, students with high Body Mass Index showed high level of motor fitness high only on chin ups in comparison with low and high BMI male school going children.

\section{Conclusions}

1. Middle BMI group and high BMI group were equal on vertical jump (explosive leg strength).

2. Middle BMI group having more muscular strength compare to high BMI group.

3. Middle BMI group and high BMI group having equal flexibility.

4. Middle BMI group are having more speed and agility compare to high BMI group. 
5. There was no significant of difference on vertical jump between low BMI group and high BMI group.

6. High BMI group having low muscular strength compare to low BMI group.

7. There was no difference on flexibility between low and high BMI group.

8. Low BMI group having more speed and agility compare to high BMI group.

9. Low BMI group and middle BMI group are equal on vertical jump.

10. There was no difference on chin up between low and high BMI group.

11. On flexibility component, low BMI group and high BMI group are equal.

Low BMI group are superior on speed agility compare to middle BMI group.

\section{References}

Bray. G.A. 1985. Complications of obesity. J. Med. 103: 1059

Kansal, D. K. 1996. Test and Measurement Delhi: D. V. S. Publication,

Kraus H. and Rabb, W. 1961. Hypokinetic Disease, Illinosis: Thomas Springfield.

Morris, J. N., Adam, C., Shave, S.P.W., Strey, C., Epstiein L. and Sheehan, D. J. 1973. Vigrous Exercise in Leisure Time and the Incidence of Coronary Heart Disease Lancet", J. Med., 333-339.

Paffenbarger R. S. and Hale, W. E. 1991. Work Activity and Coronary Heart Mortality. $J$. Med., 292: 545-550.

Rothstein, Anne L. 1985. Research Design and Statistics for Physical Education Englewood Cliffs, New Jersey: Prentice Hall. 